\title{
Growing-city pollution and sanitation: causality and evidence from major cities of southwestern Nigeria
}

\author{
Aumento da polvição da cidade em crescimento e saneamento: causalidade e \\ evidências nas principais cidades do sudoeste da Nigéria
}

Temidayo Gabriel Apata[a] [iD, Sunday Idowu Ogunjimi[a], Mobolaji Morenike Okanlawon ${ }^{[b]}$, Oluwaseun Bamigboye ${ }^{[a]}$, Christopher Adara[a], Chinwe Egbunonu[a]

[a] Federal University Oye-Ekiti (FUOYE), Department of Agricultural Economics and Extension, Oye-Ekiti, Ekiti State, Nigeria

[b] Agricultural and Rural Management Training Institute (ARMTI), Department of Agricultural Management, Ilorin, Kwara State, Nigeria

How to cite: Apata, T. G., Ogunjimi, S. I., Okanlawon, M.M., Bamigboye, O., Adara, C. \& Egbunonu, C. (2019). Growing-city pollution and sanitation: causality and evidence from major cities of southwestern Nigeria. urbe. Revista Brasileira de Gestão Urbana, v.11, e20180189. https://doi.org/10.1590/2175-3369.011.e20180189

\section{Abstract}

Growing-city pollution is seen as an inability of an existence infrastructural facilities to support the growing population of humans or other living species in that environment. Growing-city pollution amidst the world has become a topic of increased scholarly review. Yet, insignificant attention has been given to how rising city-pollution influences public health and standard of living. This paper examines the link between growingcity pollution and sanitation. Analysis uses cross-sectional data to examine this causality using an evidence of high populated cities in Southwest, Nigeria. About 6.2\% uses modern toilet facilities and about $67 \%$ practises open defecation. Access to water/sanitation facilities, distance to nearest health clinic or hospital are the main features influencing multidimensional poor sanitation/hygiene index. Focus Group Discussions (FGDs) revealed that discussants lacked an understanding of the linkages between hygiene practices and water-related diseases. Growing-city pollution influences endemic chronic diseases because sanitation is poorly accessible. Interaction between sanitation and population density in predicting poor health outcomes as evidenced in this study. Efforts should be geared by all stakeholders to boost and create livelihoods activities that can curtail rural-urban drift. Rural migrants should be encourage to stay in their vicinity to enjoy less air-polluted environment and decent accommodation.

Keywords: Sanitation measures. Core Welfare Indicator. Waste management decomposition. Indigent attitudes. Sensitization programme.

TGA is PhD, e-mail: dayo.apata@fuoye.edu.ng

SIO is PhD, e-mail: sunday.ogunjim@fuoye.edu.ng

MMO is MsC, e-mail: mobolaji.mm@gmail.com

OB is MsC, e-mail: oluwaseuntosin90@gmail.com

CA is MsC, e-mail: chrisbabafarm@gmail.com

$\mathrm{CE}$ is MsC, e-mail: chinwe.egbunonu@fuoye.edu.ng 


\section{Resumo}

O aumento da poluição em cidades em crescimento é vista como uma incapacidade de existência de instalações de infraestrutura para suportar a crescente população de seres humanos ou animais que vivem nesse ambiente. O tema da poluição das cidades em crescimento no mundo tem se destacado nas discussões acadêmicas. No entanto, não se tem dado atenção suficiente para como este crescimento influencia na saúde pública e no padrão de vida. Este artigo examina a ligação entre a poluição crescente e saneamento. A análise utiliza dados transversais para examinar essa causalidade, usando evidências de cidades com alto índice de população no Sudoeste da Nigéria. Cerca de 6,2\% utiliza instalações sanitárias modernas e cerca de 67\% possuem práticas de defecação a céu aberto. $O$ acesso a instalações de água / saneamento, a distância de uma clínica de saúde ou hospital são as principais características que influenciam o baixo índice de saneamento / higiene. O Grupo Foco Discussões (DGF) revelou que faltava uma compreensão das ligações entre as práticas de higiene e doenças relacionadas à água. A poluição em cidades em crescimento influencia o aumento de doenças crônicas endêmicas porque o saneamento é pouco acessível. Interação entre saneamento e densidade populacional que prediz os resultados de saúde pobres é algo videnciado neste estudo. Os esforços devem vir de todas as partes interessadas para aumentar e criar atividades de meios de vida na tentativa de reduzir a deriva rural-urbana. Migrantes rurais devem ser encorajados a permanecer na proximidade para desfrutar do ambiente menos poluído e uma acomodação decente.

Palavras-chave: Medidas de saneamento. Indicador de bem-estar do núcleo. Decomposição da gestão de resíduos. Atitudes indigentes. Programa de sensibilização.

\section{Introduction}

Access to quality health facilities and environmentally-sound structures are major determinants of human well-being and can prolong life (Mark, 2015; Goldizen et al, 2016; Rui et al, 2016). But environmental pollution in form of no/poor access to sanitation could degrade life span and has been proven to have facilitated a wide variety of diseases (World Bank, 2015). Sound health status is a crucial pointer of human well-being. The health of individual does not hang only on the amount of doctors and hospitals available, but also on an unpolluted and harmless environment. Hence, what are the factors that influences environmental pollution? This is the rationale of this study. It has been argued that rising city population with no commensurate sanitation could make such city polluted, hence the term growing-city pollution. Growing-city pollution is seen as an inability of an existence infrastructural facilities to support the growing population of humans or other living species of that environment.

Growing-city pollution amidst the world has become a topic of increased scholarly review (Mahabir et al, 2016). Yet, insignificant attention has been given to how rising city-pollution influences sanitation and standard of living. Standard of living refers to life that has access to prompt sanitation, clean environment to live a healthy life (UNICEF and WHO, 2015). In several portions of the developing world, this growing-city pollution has respectively increased rates of endemics of water-borne diseases and sicknesses among the people (Aliyu \& Amadu, 2017). Past studies have argued that growing-city pollution is caused by the intensity of economic activities in urban areas that entices labour from rural in hunt of job openings for livelihood (Corburn \& Hildebrand, 2015). These economic opportunities have attracted migrants to take little-paying jobs, and often, these low-income migrants cannot secured a good residences in the urban-areas and thereby settled along susceptible locations like river-margins, water-logged and road-margins areas that are lacking basic conveniences. These areas are casual communities, with improper layout and unstructured construction that can hampered meaningful expansion and development (UN General Assembly, 2015).

Growing-city polluted areas are known for high poverty rates, and generally deficient in improved water supply and sanitation. Growing-city pollution has been link to "Slum". There are several schools of thought that characterize growing-city pollution and slums as synonymous (Bichaka \& Gutema, 2005). One school of thought argued that when growing-city becomes disorder as population grows and sanitation do not grow commensurably, the city becomes polluted. Another school describing growing-city pollution as related to slums in terms of population density, because a slum is a dense area, with minimum of 300 population or about 60-70 households living under a badly constructed choked dwellings, in unhealthy environment, 
usually with insufficient infrastructure and deficient in suitable sanitary and drinking water facilities. The incidence of growing-city pollution is topmost in sub-Saharan Africa, where about $62 \%$ of inhabitants provides informal services in the urban areas (Hutton and Varughese, 2016). Affected countries with the highest portion of growing-city pollution are; Zambia, Nigeria, Kenya, Ghana, Gabon, Eriteria, Ivory Coast, Cameroun, Burundi and Botswana, (UNCTAD, 2014).

Containing city-pollution in terms of effective sanitation coverage is one of the most serious problem facing humankind in today's world. World Health Organization (WHO) stated that sanitation is the provision of facilities or services that separate people from urine and faeces. A better-quality sanitation provision is one that hygienically divides human excreta from human interaction. Past studies indicated that about 2.59 billion persons in the world has no/poor access to appropriate sanitation, meaning they must defecate openly (Global report on human settlements, 2016). Past studies argued that the reason of human prevalent and disaster around the world resulted from ineffective waste generated being disposed (Mehta, 2014; Liu \& Gary, 2014; Onibokun \& Faniran, 2017).

Furthermore, poor sanitation triggers economic shortfalls, past studies have established that the economic cost related with deprived sanitation is significant (Peal et al, 2014; Zhao et al, 2014). In Cambodia, deprived sanitation has ran to economic deficiencies of US $\$ 448$ million per year (about US\$32 per-capita shortfall). In Vietnam, the economic losses run to about US $\$ 780$ million due to poor sanitation while in India a considerable economic losses was equivalent to 6.4\% of India's GDP in 2016 at US\$53.8 billion that is an annual effect of US $\$ 48$ per person. Mahabir et al. (2016) revealed that enhanced sanitation usually comprises of people nearer sanitation facilities, fewer waiting time, and safely disposal of human excreta. Countries with substantial access to improved sanitation are; Thailand (79\% access), Philippines $(76 \%)$, Singapore (71\%), Indonesia (69\%) and Vietnam (57\%) (Gago-Cortés \& Novo-Corti, 2015). Also, 98\% of people living in industrialized countries have access to better-quality sanitation. Hathi et al. (2014) argued that access to quality and improved sanitation have improved life longevities. But, in developing countries less than 23\% of populations have such access, poorer in SSA with less than 5\% (Sele \& Ohemeng, 2015; Aliyu \& Amadu, 2017).

Literature have argued that providing access to essential sanitation for the world's most disadvantaged populations is a step in the right direction (Satterthwaite, 2011; Chisholm \& Lahiru, 2016; Goldizen et al., 2016). These problems have held back so many developmental efforts in developing countries, mostly in SubSaharan Africa (SSA) (Oloruntoba et al., 2014, Aliyu \& Amadu, 2017). A diversity of economic and health benefits are related to enhanced water and sanitation (Shuaib et al., 2014; UNCTAD, 2014; Mehta, 2014). Awareness of the health welfares of sanitation is significant because some vital economic gains hang on assessments of health consequences (WEF, 2015). There is a compelling evidence that establishes meaningful and helpful health welfares related to improved sanitation facilities (Okpataku, 2015; Muhammed et al., 2015).

This paper pay attention to growing-city pollution and sanitation in major cities of southwestern, Nigeria, where over $63 \%$ of the city's residents live with poor/no-access to sanitation. The issue is exceptionally significant in Nigeria, since universal weight of disease data over the past two decades show that poor sanitation is a foremost basis of death in Nigeria and constitutes a main outbreaks of endemics that have resulted into deaths of many Nigerians (Sele \& Ohemeng, 2015). Therefore, the purpose of this paper is to examine factors influencing growing-city pollution and sanitation and their causality. This paper uses crosssectional data to examine this causality using an evidence of cities of Ibadan, Ajegunle and Ogbomosho in Southwest Nigeria. These cities at a point in time have reported outburst of diseases owing to poor administration of the waste produced and approach of indigent to handling waste. As a result of the outbreak and its poor handling; it has cause the government numerous billions of money to tame it and to care for those that are affected. The money expended could have been put into growth-related schemes if quality sanitation mechanisms are placed.

\section{Theoretical framework and review of literature}

Malthusian hypothesis of population revealed that population rises in a geometrical ratio, while food supply rises in an arithmetic ratio. Hence, this conflict lead to extensive poverty and malnourishment. But 
with recent technological advancement, population increases has been matched with developmental initiatives of service delivery (Malmberg Calvo, 1994; Novignon et al., 2014). Concern of this study is about the theory of population growth and sanitation, and if population growth is not properly matched with service delivery of sanitation, it could lead to disaster especially in informal settlements. Service delivery approach has been indicated as the best way to solve the ever resting problem of sanitation in our urban informal settlements but poverty and ignorance have been the barriers. The theoretical basis of the study pivots on Grossman (1972) who stated that economic nature of person is significant to access affordable quality sanitation. The study further asserted that the socio-nature of the individual as displayed by educational status, awareness of consciousness of safe health habits and access to quality sanitation ascertains the wellbeing of person.

Bichaka \& Gutema (2005) studied the factors influencing safe health position (as measured by life expectancy at birth) in SSA based on the Grossman hypothetical ideal. The study deliberates the economic (the proportion of health spending to GDP and the per-capita food availability-index), societal (illiteracy level and alcohol intake) and environmental issues (development rate and carbon monoxide discharge per-capita index). Sede \& Ohemeng (2015) examined socio-economic factors of life expectancy in Nigeria (1980 -2011), the study reveals that health status and life expectancy in Nigeria hinged on quality access to sanitation. In Nigeria approximately $85 \%$ of hospital attendance is due to preventable diseases out of which $63.5 \%$ are water, sanitation and hygiene related. Global report on human settlements (2016) have described sanitation and hygiene challenges in growing-city pollution areas to influences diseases linked to polluted drinkingwater, unhygienic food provision, weak excreta discarding and filthy household surroundings.

Outcomes of UNICEF's Multi-Indicator Cluster Appraisals in 23 African countries, displays that $44 \%$ of households needed a trip of extra than 30 minutes to collect water for sanitation purposes (UNICEF and WHO 2015). Global report on human settlements (2016) and Hutton \& Varughese, (2016) indicated that usual water gathering time's per-day for four rural locations: "Ghana (3 hours/day); Makete, Tanzania (1.8 hours/day); Tanga, Tanzania (2.7hours/day); and Zambia ( 0.5 hours/day). Hence, the average distance to collect water for sanitation purposes as the study reveals is 552 meters daily and young women often times are primarily involved.

From the above analyses and the projected variances between sceneries in water and sanitation obtainability (recent and forthcoming), this study made suppositions about time savings following water and sanitation developments built on established assessment of the proof given above. It was presumed that, on average, a household getting access to enhanced water supply and sanitation outside the home or plot will save 30 minutes per-day (range: 15 to 60 minutes), supposing six members per-household, yielding 30.4 hours conserved per-individual per year. Obviously, a 30 minute time-saving hypothesis will underrate possible time savings in some, particularly water/sanitation- insufficient areas (GLAAS, 2014).

\section{Methodology}

\section{Study areas}

Nigeria is among Sub-Saharan Africa (SSA) nations found in the western part of Africa. The country has 36 states in addition to Federal Capital Territory (FCT)-Abuja. Nigeria shares its borderline with the Nigerrepublic to the north, the Republic of Benin to the west, the republic of Cameroon and Chad republic to the east, and the Atlantic Oceans forms a coastline of about 92, 377,000 hectares, about 91,077,000 hectares are solid land area. The National Population Commission (NPC) placing the population at about 140 Million people live in Nigeria in 2006. The selected study areas are Ibadan and Ogbomosho in Oyo states and Ajegunle in Lagos. Ajegunle is a heavily populated areas characterized by weak-quality housing, considerable numbers of informal residents with usually vulnerable residence and public services. Ibadan was also chosen based on the yardsticks of Ajegunle selection. However, the choice of Ogbomosho also in Oyo state was based on the recorded epidemic of cholera in 2004 and 2014 that was influenced by to poor access to sanitation facilities (Oloruntoba et al., 2014; Akpabio, 2014; Onibokun \& Faniran, 2017). 
Figure 1 shows the position of the study area in the map of Nigeria.

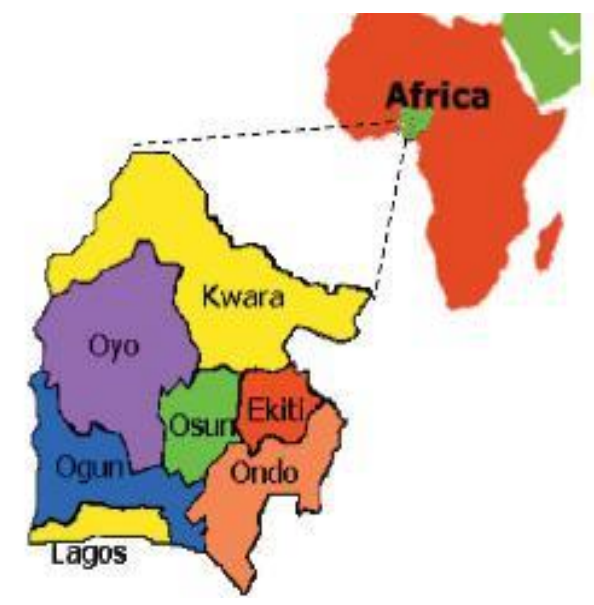

Figure 1 - www.nigerianstat.gov.ng/nada/index.php/catalog. Accessed 19th January, 2019

\section{Data collection and Methods}

Data collection for this paper relied on both secondary and primary sources. Firstly, the paper reviewed published literature on sanitation and sourced data from 2014 National Core Welfare Indicator Questionnaire (CWIQ) Survey. Secondly, primary data were on the administration of questionnaire on 350 usable respondents in the study area and Focus Group Discussions (FGDs) held in each community that was visited. Also, meetings were held with indigent and local government administrators and other shareholders in the managing of waste and delivery of sanitation. The paper adopted logit regression analysis to assess the characteristics that best describe disparity in the processes of approaches of the indigent access to potable sanitation and factors that influences it.

\section{Method of Data Analysis}

Logit model used in this paper is for the classification of individual's variables that best described access to sanitation and elements that influences it.

Simple Logit model is specified as

$$
P i(D i=1)=\frac{1}{1+e^{i i}}
$$

Ii = linear mixture of the explanatory variable of relevance in this paper (X1 to X23).

Hence,

$$
I i=\beta_{0}+\beta_{1} X_{1}+\beta_{2} X_{2}+, \ldots,+\beta_{23} X_{23}
$$

Conversely,

$$
\begin{aligned}
& P i(D i=0)=1-P i(D i=1) \\
& 1-P i(D i=1)=\frac{e^{-z}}{1+e^{-z}}
\end{aligned}
$$

Hence, equation (4) is the probability illustrations and can be converted to establish the log-odds in having access to sanitation or not. This operation is thus stated as: 


$$
\frac{P i(D i=1)=}{[1-P i(D i=1]=} \frac{1}{e^{-I i}}
$$

But

$$
\frac{1}{e^{-I i}}=e^{-I i}
$$

Therefore

$$
\frac{P i(D i=1)}{[1-P i(D i=1]}=e^{-I i}
$$

In

$$
\frac{[P i(D i=1)]}{[1-P i(D i=1)]}=e^{-I i}
$$

From equation (7), the left hand part is the odd ratio of the probability of having access to sanitation. Logarithmic equation for the estimation procedure is stated as:

$$
I i=\beta_{0}+\beta_{1} \ln _{1} X_{1}+\beta_{2} \ln _{2} X_{2}+, \ldots,+\beta_{17} \ln _{17} X_{17}
$$

Dummy variable $(\mathrm{Y})$ is $\mathrm{Di}=1$ that is access to sanitation and otherwise, $\mathrm{Di}=0$.

Logit model adopted in this paper was taken from the studies of Ghazouani \& Goaied (2001) and Rodriguez \& Smiths (1994).

Explanatory variables employed in the Logit Models equation and inferred as factors influencing households access to sanitation: access to sanitation (POVSMA), stated as 1 poor and 0, non-poor. Also, washed hands with soap each time toilet is visited (SOTOI) (X1), Household-size (HHSIZE) (X2) educational years (EDUCAT) (X3), Age (AGE) (X4), income levels (X5) in Naira, Sites and gaining easy access to waste management amenities (LAWSE) (X6), access to drinkable water (WATER) (X7), access to lavatory amenities (TOIL) (X8), uphold decent drainage (DRAIN) (X9), cleaning compound frequently (SWEEP) (X10), Residence has window/door net (DONET) (X11), home unit type (HOUSE) (X12), resources used for house's flooring (FLOOR) (X13), individual per room (PERSON) (X14), possesses an apartment (OWNDW) (X15), access to extension services (ACEXT) (X16) Dummy variable, stated as 1, access to extension services and 0, no access. Also, access to credit facilities (ACCRE) (X17), Dummy variable, stated as 1, access to credit facilities and 0 no access and Sex (X18).

\section{Results and discussions}

\section{Descriptive statistics of households' socio-economic characteristics}

Table 1 shows sex of household-heads and marital status (in percentage distribution) of selected cities. Table 1 revealed that the percentage of male-headed households is better than that of the female-headed households. Monogamy is observed by the majority of the population with Ibadan city practiced the highest monogamy. On other hand, polygamy and loose union/informal association is highest in Ajegunle, Lagos. This finding tends to confirm Ajegunle as most indecent growing-city polluted areas in Nigeria. 
Table 1 - Percentage distributions of sex of household heads 'and marital status across the selected cities in south-western Nigeria

\begin{tabular}{crrrrcccc}
\hline \multicolumn{2}{c}{ Sex } & Total & & & & \\
\hline City & Male & Female & & Single & Married & $\begin{array}{c}\text { Informal or } \\
\text { loose union }\end{array}$ & $\begin{array}{c}\text { Widowed/ } \\
\text { Separated }\end{array}$ & $\begin{array}{c}\text { Longevity } \\
\text { Years* }\end{array}$ \\
Ajegunle & 7,815 & 1,649 & 9,464 & 6.4 & 62.3 & 4.7 & 10.4 & 47 \\
Ibadan & 10,306 & 3,197 & 13,503 & 9.4 & 59.8 & 0.3 & 16.1 & 54 \\
$\begin{array}{c}\text { Ogbomoso } \\
\text { Total }\end{array}$ & 4,184 & 2,515 & 6,699 & 6.1 & 46.9 & 0.2 & 22.4 & 56 \\
& & & 29666 & & & & & \\
\hline
\end{tabular}

* Longevity years indicate life span/expectancy (National life expectancy is 53.05 years). Source: Author's computation from the 2014 National Core Welfare Indicator Questionnaire (CWIQ) Survey (2017).

Table 2a displays the percentage distribution of educational status of household-heads thru the cities. The educational years were grouped into six as: no education, certain years spent in primary school but not completed, primary education done, certain years spent in secondary, secondary school done and postsecondary attainment. The main section of the population of household-heads who had least number of educational years were found in Ibadan, while those with higher educational status in Ajegunle. This further approves Ajegunle as knowledgeable town that has produced famous footballers and Musicians in Nigeria (Onibokun \& Faniran, 2017). Average age of 49.87 years of household-heads with a variability of 33.19 percent. Ogbomoso has the utmost mean age of 53 percent and a variability index 32.85 percent. Ajegunle in Lagos State has the least mean age of 46.7 years with a variability index of 32.90 percent (Table 2a). Table $2 \mathrm{~b}$ displays the percentage distribution of household-heads occupational level across the cities. It reveals that 51.75 percent of household-heads in Ibadan are largely employed in agriculture, while Ajegunle chronicled the least household-heads that is employed in agriculture (13.37 percent) (Table 2c).

Table 2a - Percentage distributions of house heads' educational status through the designated cities in south-western Nigeria

\begin{tabular}{ccccccr}
\hline City & None & Some primary & $\begin{array}{c}\text { Completed } \\
\text { primary }\end{array}$ & $\begin{array}{c}\text { Some } \\
\text { secondary }\end{array}$ & $\begin{array}{c}\text { Completed } \\
\text { secondary }\end{array}$ & Post-secondary \\
\hline Ajegunle & 28.6 & 1.8 & 24.4 & 4.6 & 27.1 & 13.8 \\
Ibadan & 55.8 & 2.6 & 18.3 & 3.8 & 12.2 & 7.7 \\
Ogbomoso & 43.9 & 3.5 & 18.2 & 4.7 & 17.6 & 12.5 \\
\hline
\end{tabular}

Table $\mathbf{2} \mathbf{b}$ - Households' size and household head ages through the selected cities

\begin{tabular}{ccccccc}
\hline City & \multicolumn{3}{c}{ Age } & \multicolumn{2}{c}{ Household size } \\
\cline { 2 - 7 } & Mean & Std. Deviation & $\begin{array}{c}\text { Coefficient of } \\
\text { variation }\end{array}$ & Mean & Std. Deviation & $\begin{array}{c}\text { Coefficient of } \\
\text { variation }\end{array}$ \\
\hline Ajegunle & 46.7 & 15.2 & 32.5 & 4.5 & 2.3 & 50.1 \\
Ibadan & 49.8 & 16.5 & 33.7 & 3.8 & 2.5 & 60.7 \\
Ogbomoso & 52.6 & 17.4 & 32.5 & 4.1 & 2.6 & 63.4 \\
\hline
\end{tabular}

Table 2c - Occupational status through the selected cities

\begin{tabular}{ccccccccrr}
\hline City & None & Public & $\begin{array}{c}\text { Private } \\
\text { formal }\end{array}$ & $\begin{array}{c}\text { Private } \\
\text { informal }\end{array}$ & Self agric. & Self others & Jobless & Others \\
\hline Ajegunle & 2.2 & 17.7 & 6.4 & 1.3 & 13.4 & 46.9 & 1.3 & 11.3 \\
Ibadan & 3.1 & 5.2 & 1.6 & 2.7 & 51.8 & 28.7 & 0.8 & 6.3 \\
Ogbomoso & 2.7 & 7.3 & 2.3 & 1.8 & 37.6 & 36.4 & 0.5 & 10.8 \\
\hline
\end{tabular}

Source: Author's computation from the 2014 National Core Welfare Indicator; Questionnaire (CWIQ) Survey (2017).

\section{Sanitation/Hygiene indicators decomposition to welfare of the households in the designated cities}

Table 3 reveals the complete and comparative contributions of each of the features of sanitation/hygiene to multidimensional poor sanitation/hygiene. The results reveals that; resources used for flooring the house $(0.0088$ and 2.36$)$ having difficulty with supply of drinking water $(0.0096,2.53)$, key source of drinking water $(0.0082,2.20)$ type of toilet facility used $(0.0082,2.20)$ and distance to nearest health clinic or hospital (0.0094 2.50) are the main features influencing the overall multidimensional poor sanitation/hygiene index in these designated cities in Nigeria. 
Hence, awareness of healthful environment choices and quality sanitation mechanism were determined using an index. This index were used to capture number of households who adopted these measures. These measures stated as follows:

1. Regular access to efficient waste management amenities

2. Regular access to drinkable water

3. Access to quality toilet amenities

4. Uphold decent drainage

5. Clearing compound frequently

6. Wash hands with soap each time toilet visited.

Table 3 - Multidimensional sanitation and hygiene decomposition across the indicators in the selected cities

\begin{tabular}{ccc}
\hline Indicators / Characteristic & Complete contribution & Comparative contribution \\
\hline Resources used for house flooring & 0.008986 & 2.367657 \\
Home unit kind & 0.002902 & 0.764665 \\
Individual per room & 0.008077 & 2.128074 \\
Foremost basis of drinking water & 0.008341 & 2.197688 \\
Difficulties with source of potable water & 0.009673 & 2.548623 \\
Water preserved before drinking & 0.002835 & 0.747262 \\
Kind of toilet capacity & 0.008333 & 2.195450 \\
Kind of waste collection & 0.006015 & 1.584860 \\
Uphold decent drainage & 0.000595 & 0.156960 \\
Uphold decent sanitation & 0.002030 & 0.535191 \\
Apartment has window/door net & 0.001145 & 0.301987 \\
Possesses the apartment & 0.006543 & 1.724075 \\
Access to refuse dump or refuse collectors & 0.007025 & 1.850958 \\
Members apparent family to be poor & 0.007106 & 1.872286 \\
Educational level of head of household & 0.006008 & 1.582940 \\
Regular use of bed net to avoid malaria & 0.003493 & 0.920550 \\
Distance to collect drinking water & 0.004483 & 1.181385 \\
Distance to nearby health clinic/hospital & 0.009542 & 2.514130 \\
\hline
\end{tabular}

Source: Author's computation from the 2014 National Core Welfare Indicator; Questionnaire (CWIQ) Survey (2017).

The paper made an inquiries about household living conditions, expenditures, safety, disease, and selfrated health issues (table 4). Table 4 revealed that life expectancy (LE) in the study areas is limited to 52.6 years, compare to national life expectancy of 53.05 years. Life expectancy in developed countries with quality access to sanitation such as Singapore, Norway among others are 84 years (Gago-Cortés \& Novo-Corti, 2015). Population density (PD) is an estimation of ratio of people to land area, (i.e., population per unit of land area). PD in the study areas are quite large considering world economic indicators. Comparing with the world indicator of 50.9 people per-square kilometre, or 132 people per square mile. When comparing with poverty status, the paper revealed a strong correlation. Could growing-city pollution be as a result of poverty? Although, there are cities in the world that has a very high PD. Macau city in China, has 48,100 people per square-mile. Singapore city has 18,100 per square-mile. Taiwan has 1657 per square mile. Holland has 1036 and Japan has 874 per square-mile. When compared these high PD cities with poverty status, it varies between $12-25 \%$. This is quite low, thus suggesting that PD is not correlated to poverty. Belgium has a very high population density, but their poverty status is 6.2 (Global report on human settlements 2016). Japan has a relatively small land endowments with high PD but the country is amongst the richest countries in the world. The study also revealed that in the study areas sanitation is poor as majority (95\%) blamed the act of inadequate planning to be the major cause of poor sanitation. Also, about $67 \%$ of the respondents indicated that often times landlords/houseowner's do not built toilets facilities when they erected apartments but rather concentrated on increasing their income by building more houses.

The paper also indicated that long distance to health facilities for health concerns, a high correlation of this indicator to poverty status and short life span was signified (Table 4). Moreover, respondents (31.3\%) depend on the use of latrine as their major sanitation facilities, while $6.2 \%$ uses modern toilet facilities. There are about $57.3 \%$ respondents that acknowledged that the cost of paying for sanitation was exorbitant to them and thus they chose to use container, cans and polythene bags while others easing themselves outside in drainages especially at night. The paper observed that the use of latrines in the study areas is also a major contributor to pollution as latrines are constructed to discharge inside dam or stream/river alongside and 
when it rains some end up over flooding and the resultant effect is the floating faecal waste all over which does not enhanced environmental quality. Hence, residents are expose to impurity, disease and infection influencing health threats.

Table 4 - Measurement of Indicators of Good Living conditions among respondents ( $N=350)$

\begin{tabular}{ccccccc}
\hline Town & Life expectancy & Population & Population Density & $\begin{array}{c}\text { Sanitation } \\
\text { amenities }\end{array}$ & $\begin{array}{c}\text { Distance }(\mathbf{k m}) \text { to } \\
\text { Health facilities }\end{array}$ & $\begin{array}{c}\text { Poverty status } \\
\text { (\%) }\end{array}$ \\
\hline Ajegunle & 47 & $1,555,000$ & $750 / \mathrm{Km}^{2}$ & 0.15 & 6.25 & 71 \\
Ibadan & 54 & $3,034,200$ & $464 / \mathrm{Km}^{2}$ & 0.28 & 3.13 & 68 \\
Ogbomosho & 57 & 645,000 & $253 / \mathrm{Km}^{2}$ & 0.36 & 2.61 & 66 \\
\hline
\end{tabular}

Sources: ClA World Fact book (2017); Department of Economic and Social Affairs (population division) of United Nations (World Urbanization projections 2014 revision); National Demographics Data Review 2017 (National Bureau of Statistics).

The study areas revealed a poor sanitation as a main cause of the widespread communicable diseases and these are major complaints of health concerns in hospitals/health center. These communicable diseases comprises of diarrhea, typhoid, malaria, respiratory tract problems, skin infections eye and ear infections amid others.

Table 5 revealed mean income was $\$ 109,353.35$ for the pooled data but household-head from Ajegunle earned more by $45.6 \%$. Moreover, the annual mean income translated to $8,425.67$ (USD 26.62) monthly, which is far below the $\$ 18,000$ minimum wage in the country, showing that they barely survived on $\$ 0.89$ per day which is beneath the poverty line of $\$ 1.25 /$ day. Average of one person had sickness in all the zones. If an illness is perceived to be less severe, the probability of choosing self-medication would be high and if otherwise, the probability of seeing a consultant for health care would be high (Lui \& Yamauchi, 2014; Jianhua et al., 2016). Work distance of $6.25 \mathrm{~km}$ and treatment cost of $\$ 51,603.69 \mathrm{in}$ Ajegunle were the highest. The implication is that household-heads in that zones could spend more days nursing sickness resulted from poor access to sanitation amenities. Years of education mean (8.7 years) was the highest in all the zones meaning that household-heads in the area were not expected to experience prolonged absence due to their level of education which could assist in taking the right steps towards sickness cure and maintaining decent living. The least educated household-head was recorded in Ogbomosho and this could have implication for sickness presence.

Table 5 - Selected Descriptive statistics - Covaraites

\begin{tabular}{ccccccccc}
\hline & \multicolumn{2}{c}{ Ogbomosho } & \multicolumn{2}{c}{ Ibadan } & \multicolumn{2}{c}{ Ajegunle } & \multicolumn{2}{c}{ Pooled } \\
Variables & Mean & $\begin{array}{c}\text { Std. } \\
\text { Deviation }\end{array}$ & Mean & $\begin{array}{c}\text { Std. } \\
\text { Deviation }\end{array}$ & Mean & $\begin{array}{c}\text { Std. } \\
\text { Deviation }\end{array}$ & Mean & Std. \\
Deviation
\end{tabular}

Computer results. $\mathrm{N}=350$. Source: Field study (2017).

Table 6 further shows the strength of the relationship between some of the significant variables and the dependent variable. The Pearson Correlation shows that the covariates exhibited moderate with dependent variables, access to effective sanitation improves health and productivity. In addition, number down with sickness, work distance, waiting time, choice of sanitation adopted, and availability of sanitation significantly influenced sound health. Also, there is a direct relationship between health status and the dependent variable (access to quality sanitation). Likewise, positive relationship exists between sickness perception and 
sickness absence rate, and the marginal effect showed a discrete change in sickness absence rate by 0.02 as sickness perception changes from 0 to 1 .

In the same vein, the number of household member down with sickness had positive relationship with the dependent variable indicating that a unit increase in poor sanitation access could lead to an increase of $1.7 \%$. Work distance is significant $(\mathrm{p}<0.10)$ but exhibits indirect relationship with the dependent variable meaning that increase in work distance would influence health status by $0.3 \%$. Waiting time is significant and with the expected sign. Availability of sanitation is significant at $p<0.01$ and positive, meaning that the more access to quality sanitation, the less frequent to hospital/clinics.

Table 6 - Pearson Correlation Matrix showing the relationship between variables ( $N=350$ )

\begin{tabular}{ccccccccc}
\hline & $\begin{array}{c}\text { Number of Days } \\
\text { absent from } \\
\text { work }\end{array}$ & $\begin{array}{c}\text { Treatment } \\
\text { cost }\end{array}$ & $\begin{array}{c}\text { Number } \\
\text { down with } \\
\text { Sickness }\end{array}$ & $\begin{array}{c}\text { Farm } \\
\text { distance }\end{array}$ & $\begin{array}{c}\text { Waiting } \\
\text { Time }\end{array}$ & $\begin{array}{c}\text { Availability } \\
\text { of sanitation }\end{array}$ & $\begin{array}{c}\text { Age of } \\
\text { Household } \\
\text { Head }\end{array}$ & $\begin{array}{c}\text { Choice of } \\
\text { Sanitation } \\
\text { adopted }\end{array}$ \\
\hline Number of Days absent & & $.137^{* *}$ & $.219^{* *}$ & $-.217^{* *}$ & $.317^{* *}$ & $.414^{* *}$ & .014 & $-.241^{* *}$ \\
Treatment cost & $.137^{* *}$ & & $.348^{* *}$ & $-.204^{* *}$ & $.201^{* *}$ & $.304^{* *}$ & .038 & $-.137^{* *}$ \\
Number down with Sickness & $.219^{* *}$ & $.348^{* *}$ & & $-.351^{* *}$ & $.206^{* *}$ & $.418^{* *}$ & $.181^{* *}$ & $-.211^{* *}$ \\
Work distance & $-.217^{* *}$ & $-.204^{* *}$ & $-.351^{* *}$ & & $-.132^{* *}$ & $-.191^{* *}$ & $.073^{*}$ & .072 \\
Waiting Time & $.317^{* *}$ & $.201^{* *}$ & $.206^{* *}$ & $-.132^{* *}$ & & $.279^{* *}$ & .041 & $-.261^{* *}$ \\
Availability of sanitation & $.414^{* *}$ & $.304^{* *}$ & $.418^{* *}$ & $-.119^{* *}$ & $.279^{* *}$ & & $.082^{*}$ & $-.213^{* *}$ \\
$\quad$ Age of H-Head & .014 & .038 & $.181^{* *}$ & $.073^{*}$ & .041 & $.082^{*}$ & $-.116^{* *}$ \\
Choice of sanitation adopted & $-.241^{* *}$ & $-.137^{* *}$ & $-.211^{* *}$ & .072 & $-.261^{* *}$ & $-.213^{* *}$ & $-.116^{* *}$ & -.12 \\
\hline
\end{tabular}

**. Correlation is significant at the 0.01 level (2-tailed). Source: Questionnaire (CWIQ) Survey (2017). Authors' computation from the 2014 National Core Welfare Indicator (2017).

The dependent variable is a dummy variable $(\mathrm{Y})$ which is defined as $\mathrm{Di}=1$ access to sanitation and $\mathrm{Di}=0$, otherwise. An index was used to calculate access to sanitation or not as expressed in table 3, multidimensional sanitation and hygiene decomposition. The result of the logit regression inquiry from Table 7 reveals that wash hands with soap each time toilet visited, educational years, household size, access to potable drinking water, access to waste management services, regular access to toilet facilities, cleaning compound frequently, maintain good drainage, apartment has window/ door net, number of rooms per person, resources used for flooring the house and sex are the factors influencing sound health. The results specified that household size; resources used for house flooring and individual per room remained significant and negative. This result implies that the bigger the household size, the worse the sanitation. The outcomes also exposed that wash hands with soap each time toilet visited, educational years, access to waste management amenities, access to drinkable water; cleaning of compound frequently; maintain good drainage; access to toilet; apartment has window/door net and sex of household-heads all had significant and positive effect (Table 7).

Table 7 - Logit Regression Estimates of Quality Health Determinants

\begin{tabular}{|c|c|c|}
\hline Variable & Estimate & t-value \\
\hline Washed hands with soap each time toilet is visited & 090E-01 & $4.33^{* * *}$ \\
\hline Household-size & $-.308 \mathrm{E}-01$ & $-2.88^{* *}$ \\
\hline Level of education & .43 & $3.43^{* * *}$ \\
\hline Age & $-.161 \mathrm{E}-01$ & -.35 \\
\hline Occupational experience & -.89 & -.29 \\
\hline Sites and gaining easy to waste management amenities & .63 & $2.71^{* *}$ \\
\hline Access to drinkable water & .58 & $2.73^{* *}$ \\
\hline Access to lavatory amenities & $.22 \mathrm{E}-04$ & $2.14^{*}$ \\
\hline Uphold decent drainage & 933Е-05 & $2.13^{*}$ \\
\hline Clearing compound frequently & .72 & $2.75^{* *}$ \\
\hline Residence has window/door net & $.827 \mathrm{E}-06$ & $2.13^{*}$ \\
\hline Home unit type & $.923 \mathrm{E}-01$ & 1.43 \\
\hline Resources used for house's flooring & $-.135 E+10$ & $-4.43^{* * *}$ \\
\hline Individual per room & $-.5196 \mathrm{E}-03$ & $-2.58^{*}$ \\
\hline Possesses an apartment & -.12 & -.13 \\
\hline Access to extension services & .24 & .35 \\
\hline Access to credit facilities (ACCRE) & .37 & $2.73^{* *}$ \\
\hline
\end{tabular}


* Significant at $p<0.001,{ }^{* *}=$ Significant at $p<0.005,{ }^{* * *}=$ Significant at $p<0.001$, Log-likelihood Estimates: -198.75 , Significance level: 7951 Constant = 0.6292. Source: Logit Regression Results (Computer Printout).

The study indicated that control measures were not really practiced by all the households in the selected cities (Table 8). Further decomposition analysis indicated that wash hands with soap each time toilet visited were only practiced in Ajegunle (72\%), while Ibadan and Ogbomoso recorded a very low participation (Table 8). These selected cities indicated a very weak drainage. This outcome imply that insight of healthful environment choices are powerfully affected by educational attainment, sites and access to waste management authority among others. Households with numerous members but no access to waste management amenities are more likely to have numerous wastes cluttered around. Effective access to waste management amenities enables decent environment. Moreover household-head with high/moderate educational attainment presents decent environment.

Table 8 - Percentage of Household heads who practiced sanitation control across the selected cities

\begin{tabular}{cccc}
\hline Control measures & Ajegunle & Ibadan & Ogbomoso \\
\hline Locations and access to waste management services & 0.61 & 0.22 & 0.27 \\
Access to potable drinking water & 0.33 & 0.16 & 0.36 \\
Access to toilet facilities & 0.44 & 0.28 & 0.52 \\
Maintain good drainage & 0.21 & 0.15 & 0.34 \\
Sweeping compound regularly & 0.36 & 0.29 & 0.47 \\
Washing hands with soap after toileting & 0.73 & 0.26 & 0.19 \\
\hline
\end{tabular}

Source: Computation from CWIQ 2014.

Table 9 - Cross tabulation of control measures and some important indicators index that influence good sanitation measures (measure by percentage).

\begin{tabular}{cccc}
\hline Control measures & Household size & Educational Status & Perception indicators \\
\hline Locations and access to waste management services & 0.23 & 0.77 & 0.86 \\
Access to potable drinking water & 0.20 & 0.68 & 0.92 \\
Access to toilet facilities & 0.16 & 0.81 & 0.52 \\
Maintain good drainage & 0.42 & 0.76 & 0.93 \\
Sweeping compound regularly & 0.56 & 0.67 & 0.66 \\
Washing hands with soap after toileting & 0.17 & 0.71 & 0.86 \\
\hline
\end{tabular}

Source: Authors 2014.

Results of the Interview with the Indigent Households

Focus Group Discussions (FGD) was carried out during the month of March through September, 2017 and 320 households were directly involved in the designated cities. From the discussions, it was revealed that numerous calls per-day to a toilet or for vulnerable defecation site outdoor (particularly for women) are common. Also, postulation was made of 30 minutes saved per-person per-day, for latrines in the apartment or compound, conveying 182.5 hours per-person per-year saved. Estimate of time savings will be possible if enhanced better access to water and sanitation are available and with latrines closer/inside apartment.

\section{Summary of the Findings of FGD}

Focus group discussants were short of an insight of the relationships between hygiene practices and water-related diseases. While the people acceded that excreta are 'immoral', none of them understand that relationship between polluted water and diseases very necessary. "Latrines and hygiene practices were also a substance to local taboos and traditions". People argued, for example, that practice of compelling children to sip the water that the entire family has used for washing their hands make the children stronger. Some of the discussants felt that go into a latrine was like entering a house - and, indeed one that was stinking and, as such, rather horrible to be in. Being in an enclosed room and hence was seen as an unsuitable environment for defecating. There was a robust impression in all deliberations that the choice to invest in and to build a latrine falls within the male purview. As such, even if a woman desired a latrine, she would still need permission from her husband. "The man takes the decision: he indicates the location, digs the hole and pays for the materials. However, men do not generally see latrines as a priority, 'Some discussants linked latrines 
absolutely with urban life and as 'a white man's concern' which they wanted to copy. This was specifically the case where members of a family had travelled to the town and invested in a latrine upon their return. Moreover, sanitation policies and programmes are determined exclusively by the government without the contribution of the local people. Hence, this is why most government policies are not effectual. To be effectual, as proposed by the people, it must be community-demand-driven and local people must also be seen as a shareholder in appropriate sanitation processes.

Discussants brought up lack of financial resources to purchases soap and toiletries. Also, lack resources to employ labour to dig a hole for latrines and accompanied materials such as cement/slab. Discussants also identified various factors that discourage the construction of latrines. So, what exactly limits better-quality hygiene and sanitation in these selected cities and how can their present situation be improved upon? At which stage is the sector policy presently and foremost obstacles and helpful factors for its development? The paper take a shot to the institutional and policy setting that administers the sanitation/environmental sub-sector in Nigeria.

The results showed that in the study areas and some parts Nigeria, sanitation and hygiene are still at a poor stage. Though there has been a national environmental day and sanitation plan since 1984 and a legal agenda since 1998 but these policies have stayed underdeveloped. This also goes for hygiene advancement: a hygiene programme and strategy that was instituted during 1998-2006. Furthermore, the national sanitation policy of 1998, the federal capital territory (FCT) and some portions of Lagos Island have established detailed sanitation strategies in conjunction with a World Bank scheme on urban water and wastewater administration. This denotes that FCT and some sections of Lagos are the lone areas with a sanitation action strategy, structure and financing processes. Thus, rural areas and mostly small and medium towns in Nigeria have been totally ignored with no clear plan, no budget and no delivery procedures.

The selected cities examined are noted for high and rising population and the FGD revealed that refuse collectors are scarce and if available expensive. Most times there are no refuse collectors and this has forced many people to dump their refuse and waste anyhow. Studies have revealed that improper management of refuse and waste increases emit carbon dioxide, methane and nitrous oxide into the atmosphere and thus enhances global warming (IRENA, 2015).

\section{Conclusions and policy implication}

Hand washing is effectual when it is practiced as indicated, but how can the essential behavioural change be accomplished? Most hand washing campaigns are effectual in the short term because age-long behaviour relapses soon after the campaign finishes. A hopeful exclusion must links to a thorough house visits, radio messages and educating of health-centre staff to keep prompting the impact of practicing decent sanitation measure among people. Enhanced sanitation comprises of better access and safer discarding of human excreta with well-covered septic tank, modest pit latrine, and well-aerated modern pit latrine coupled with effective modern sewage control systems.

Common disbelief between different attitudes is often an obstacle to successful sanitation and hygiene delivery in the study areas. Policy-makers argued that sanitation must be a household concern, so that public agencies can converge their energies on public aspects of sanitation and waste/refuse collection/control. However, eradicating excreta from living areas has foremost health benefits, not just for single families, but also for their fellow-occupants and environment. Practising good health systems is of immense to all. Thus, enhanced sanitation are enjoyed by the community at large, rather than be credited principally to individual households. In line with this view, such externalities explain the use of public funds for latrine campaign. Consequently public institutions, both central and decentralised, have a concern in-and duty towardsassigning public resources for household and minor community-level sanitation enhancements.

Evidence from the study areas indicated that growing-city pollution influences endemic chronic disease of diarrhea, typhoid, malaria, skin infections among others. These disease are caused by poor/non-existence sanitation which influences reduction in life span, economic and productivity loss. Past studies have shown that rising population is not the problem, but planning, for instance, Stockholm, Hong Kong and Singapore cities are densely populated and yet residents have access to quality sanitation. These countries are exceptionally clean because government invested massively in infrastructural development particularly 
water and sanitation. Sanitation is important not only for healthy living but also for ensuring a non-polluted environment. Recent econometric studies suggest an interaction between sanitation and population density in predicting health outcomes in developing countries as evidenced in this study.

The study identified key contributor to poor sanitation levels, because people regarded access to sanitation as very costly and thus influence massive open defecation. Moreover, house owners were ignorant of the fact that sanitation provisions are important when building. Consideration must be directed to intensifying latrine coverage and hygiene advancement. Community need to be educated on the importance of better sanitation. Access to sanitation is a fundamental human-right, hence, there is need for effective dissemination of information (through workshops/seminars/extension officers) on the importance of promoting environmental cleanliness. Erecting toilet facilities close to the residence when building and establishment of a better solid waste management. One of the major factors influencing rural-urban drift is economic opportunities in the cities. Efforts should be geared by all stakeholders to boost and create livelihoods activities in the rural areas to curtail this drift.

\section{Conflict of Interest Statement}

There is no conflicts of interest and the work is a personal efforts. No form of funding was accessed.

\section{References}

Akpabio, E., Aquite, M., \& Kaoru T. (2014). Understanding and confronting cultural complexities characterizing water, sanitation and hygiene in Sub-Saharan Africa. Water International, 39(7), 921-932.

Aliyu, A., \& Amadu, L. (2017). Urbanization, Cities, and Health: The Challenges to Nigeria A Review. Annals of African Medicine, 16(4), 149-158.

Bichaka, F., \& Gutema, P. (2005). The determinants of health status in Sub-Saharan Africa (SSA). American Economics, 42(2), 60-72.

Chisholm, R., \& Lahiru W. (2016). The Need for Long-term Remedies for Indonesia's Forest Fires, Conservation Biology, 30, 5-16.

Corburn, J., \& Hildebrand, C. (2015). Slum Sanitation and the Social Determinants of Women's Health in Nairobi, Kenya. Journal of Environmental and Public Health Volume 2015, Article ID 209505, 6 pages.

Gago-Cortés, C., \& Novo-Corti, I. (2015) Sustainable development of urban slum areas in north western Spain. Management of Environmental Quality, 26(6):891-908. doi: https://doi.org/10.1108/MEQ-06-2014-0095Public

Grossman, M. (1972). On the Concept of Health Capital and the Demand for Health. Journal of Political Economy, 80, 223-255. doi: 10.1086/259880.

Ghazouani, S., \& Goaied, M. (2001). The determinants of urban and Rural poverty in Tunisia. World Bank. Working Paper 0126.

GLAAS (UN-water Global Analysis and Assessment of Sanitation and drinking-water). (2014). Investing in water and sanitation: Increasing access, reducing inequalities. Geneva: World Health Organization (WHO).

Global report on human settlements (2016). United Nations Human Settlements Programme. First published in the UK and USA in 2003 by Earthscan Publications Ltd for and on behalf of the United Nations Human Settlements Programme (UN-Habitat)

Goldizen, F. C., Peter D., \& Luke D. (2016). Respiratory Effects of Air Pollution on Children, Pediatric Pulmonology, 51, 37-99.

Hathi, P., Haque, S., Pant, L., Coffey, D., \& Spears, D. (2014). Place and Child Health: The Interaction of Population Density and Sanitation in Developing Countries. Water Global Practice Group of the World Bank: Policy Research Working Paper 7124. 
Hutton, G., \& Varughese, M. (2016). The Costs of Meeting the 2030 Sustainable Development Goal Targets on Drinking Water, Sanitation, and Hygiene Summary Report. Joint publication and collaborative effort by the World Bank, the United Nations Children's Fund (UNICEF), the World Health Organization (WHO).

IRENA (International Renewable Energy Agency). 2015. Renewable Energy in the Water, Energy and Food Nexus. Accessed on 25th October 2017, from http://www.irena.org/menu/index.aspx

Jianhua, N., Tianlu, Q., Changbai, X., Yikang, R. \& Jiechen, W. (2016). Spatial Distribution Characteristics of Healthcare Facilities in Nanjing: Network Point Pattern Analysis and Correlation Analysis. International. Journal. Environmental. Research on Public Health, 13, 833-846, doi: 10.3390/ijerph13080833

Liu, J., \& Gary, L. (2014). Environmental Toxicity and Poor Cognitive Outcomes in Children and Adults, Journal of Environmental Health, 76(6), 130-138.

Mahabir, R., Crooks, A. Croitoru, A. \& Agouris, P. (2016) The study of slums as social and physical constructs: challenges and emerging research opportunities, Regional Studies, Regional Science, 3(1), 399-419, doi:

$10.1080 / 21681376.2016 .122913$

Mark, J. (2015). Green Spaces and Cognitive Development in Primary Schoolchildren, Proceedings of the National Academy of Sciences, 112(26), 7937-7942.

Mehta, S. (2014). Effect of Poverty on the Relationship between Personal Exposures and Ambient Concentrations of Air Pollutants in Ho Chi Minh City Atmospheric Environment, 95, 571-580.

Malmberg Calvo, C. (1994). Case study on the role of women in rural transport; access of women to domestic facilities. World Bank: Sub-Saharan Africa Transport Policy Program, Working Paper No. 11.

Muhammed, S., Sabiu, N., \& Khalil, M. (2015). An overview of urbanization and its challenges on sustainable development in Nigeria. Dutse Journal of Pure and Applied Sciences, 1(1), 19-29.

National Core Welfare Indicator Questionnaire (CWIQ) Survey (2017). National Bureau of Statistics (NBS). Retrieved on 21st January, 2019, from nigerianstat.gov.ng/nada/index.php/catalog 2018

Novignon, J., Olakojo, S.A., \& Nonvignon, J. (2014). The effects of public and private health care expenditure on health status in sub-Saharan Africa: new evidence from panel data analysis. Health Economics Review 22(2), 22-31.

Okpataku, C. I. (2015). Pattern and reasons for substance use among long-distance commercial drivers in a Nigerian city. Indian Journal of Public Health, 59, 259-263.

Onibokun, A. \& Faniran, A. (2017). Urbanization and Urban Problems in Nigeria. Urban Research in Nigeria. Accessed on 10th Dec. 2017, from: http://www.books.openedition.org/ifra

Oloruntoba, E. O., Folarin, T.B., \& Ayede, A.I. (2014). Hygiene and sanitation risk factors of diarrhoeal disease among under-five children in Ibadan, Nigeria. African Health Science, 14, 1001-1011.

Peal, A., Evans, B., Blackett, I., Hawkins, P., \& Heymans, C. (2014). Fecal Sludge Management: A Comparative Analysis of 12 Cities. Journal of Water, Sanitation and Hygiene for Development, 4(4), 563-75.

Rodriguez, A., \& Smith, M. (1994). A comparison of determinants of urban, rural and farm poverty in Costa Rica. World Development, 22(5), 1-16. doi: https://doi.org/10.1016/0305-750X(94)90054-X

Rui, Y.; Yang, Z.; Qian, T.; Khalid, S.; Xia, N., \& Wang, J. (2016). Network-constrained and category-based point pattern analysis for Suguo retail stores in Nanjing, China. International Journal of Geography Information Science, 30, $186-199$.

Satterthwaite, D. (2011). How urban societies can adapt to resource shortage and climate change, Philosophical Transactions of the Royal Society, A: Mathematical, Physical and Engineering Sciences, 369(1942), 1762-1783.

Sele, P. \& Ohemeng, W. (2015). Socio-economic determinants of life expectancy in Nigeria. (1980 -2011). Health Economics Review, 5(2), 1-16.

Shuaib, F., Musa, E., Mahoney, F., Oguntimehin, O., \& Nguku, P. (2014). Ebola virus disease outbreak-Nigeria. Morbidity Mortal Weekly Report, 63, 867-872.

UNCTAD (UN Conference on Sustainable Development). (2014). The Least Developed Countries Report 2014. Growth with Structural Transformation: A Post-2015 Development Agenda. Geneva: UNCTAD Secretariat. 
UN General Assembly. (2015). Transforming Our World: The 2030 Agenda for Sustainable Development. Resolution adopted by the General Assembly on 25 September 2015.A/RES/70/1. New York: United Nations.

UNICEF and WHO (UN Children's Fund and World Health Organization). (2015). Progress on Drinking Water and Sanitation: 2015 Update and MDG Assessment. WHO/UNICEF Joint Monitoring Programme for Water Supply and Sanitation. Geneva: WHO.

World Bank (2015) World Development Indicators Database. World Bank, Washington, DC, USA.

WEF (World Economic Forum) (2015). Global Risks 2015. Tenth Edition. Accessed from: http://reports.weforum.org/global-risks-2015/

Lui, Y. \& Yamauchi, F. (2014) Population density, migration, and the returns to human capital and land: Insights from Indonesia. Food Policy, 48, 182-193.

Zhao, X., Sufang, Z., \& Chunyang, F. (2014). Environmental Externality and Inequality in China: Current status and future choices, Environmental Pollution, 190, 176-179.

Editor: Harry Bollmann

Recebido: Mar 2, 2019

Aprovado: Maio 22, 2019 